\title{
Marked enlargement of neck circumference from nerve hypertrophy in CIDP
}

\section{Figure \\ Clinical and MRI correlation of cervical nerve hypertrophy in chronic inflammatory demyelinating} polyradiculoneuropathy
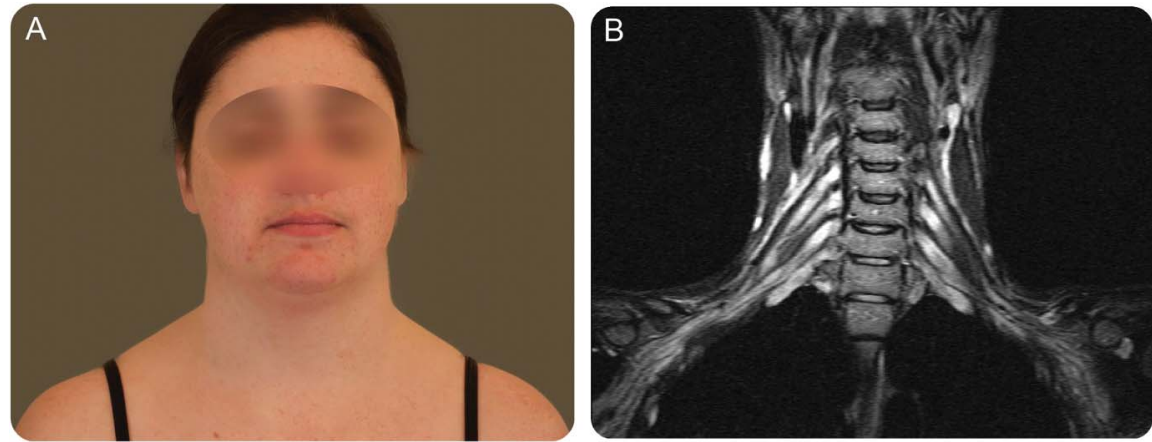

(A) Striking uniform enlargement of the neck and upper trapezius region developed insidiously over the last decade. It was not of concern to the patient. (B) MRI coronal short tau inversion recovery image shows hyperintensity and marked hypertrophy of all cervical nerves and trunks of the brachial plexus.

Painless enlargement of the neck is most often due to adiposity, goiter, or lymphadenopathy. The figure, A, demonstrates how diffuse hypertrophy of cervical spinal nerves and trunks can also produce a clinically obvious increase in neck circumference.

The patient is a 35-year-old woman with teenage-onset chronic inflammatory demyelinating polyradiculoneuropathy (CIDP), confirmed by nerve conduction studies, raised CSF protein, MRI (figure, B), and response to treatment.

Nerve hypertrophy in CIDP is often prominent in proximal elements of the peripheral nervous system. It is typically revealed by MRI ${ }^{1}$ but not obvious clinically. In contrast, palpable enlargement of distal cutaneous branches is more common in hypertrophic forms of Charcot-Marie-Tooth disease.

Pierre R. Bourque, MD, Thanh B. Nguyen, MD, Jocelyn Zwicker, MD, Jodi Warman Chardon, MD

From The Ottawa Hospital (P.R.B., T.B.N., J.Z., J.W.C.), University of Ottawa (P.R.B., T.B.N., J.Z., J.W.C.), and Children’s Hospital of Eastern Ontario (J.W.C.), Ottawa, Canada.

Author contributions: Pierre Bourque: acquisition of data, intellectual content. Thanh Nguyen: acquisition of radiologic data. Jocelyn Zwicker: critical revision of manuscript for intellectual content. Jodi Warman Chardon: critical revision of manuscript for intellectual content.

Acknowledgment: The authors thank Janine Klaas for clinical photography.

Study funding: No targeted funding reported.

Disclosure: The authors report no disclosures relevant to the manuscript. Go to Neurology.org for full disclosures.

Correspondence to Dr. Bourque: pbourque@toh.ca

1. Adachi $\mathrm{Y}$, Sato N, Okamoto $\mathrm{T}$, et al. Brachial and lumbar plexuses in chronic inflammatory demyelinating polyradiculoneuropathy: MRI assessment including apparent diffusion coefficient. Neuroradiology 2011;53:3-11. 


\title{
Neurology
}

\author{
Marked enlargement of neck circumference from nerve hypertrophy in CIDP \\ Pierre R. Bourque, Thanh B. Nguyen, Jocelyn Zwicker, et al. \\ Neurology 2016;87;442 \\ DOI 10.1212/WNL.0000000000002901
}

This information is current as of July 25, 2016

\begin{tabular}{|c|c|}
\hline $\begin{array}{l}\text { Updated Information \& } \\
\text { Services }\end{array}$ & $\begin{array}{l}\text { including high resolution figures, can be found at: } \\
\text { http://n.neurology.org/content/87/4/442.full }\end{array}$ \\
\hline References & $\begin{array}{l}\text { This article cites } 1 \text { articles, } 0 \text { of which you can access for free at: } \\
\text { http://n.neurology.org/content/87/4/442.full\#ref-list-1 }\end{array}$ \\
\hline Subspecialty Collections & $\begin{array}{l}\text { This article, along with others on similar topics, appears in the } \\
\text { following collection(s): } \\
\text { Chronic inflammatory demyelinating polyneuropathy } \\
\text { http://n.neurology.org/cgi/collection/chronic_inflammatory_demyelinat } \\
\text { ing_polyneuropathy } \\
\text { Clinical neurology examination } \\
\text { http://n.neurology.org/cgi/collection/clinical_neurology_examination } \\
\text { MRI } \\
\text { http://n.neurology.org/cgi/collection/mri } \\
\text { Peripheral neuropathy } \\
\text { http://n.neurology.org/cgi/collection/peripheral_neuropathy }\end{array}$ \\
\hline Permissions \& Licensing & $\begin{array}{l}\text { Information about reproducing this article in parts (figures,tables) or in } \\
\text { its entirety can be found online at: } \\
\text { http://www.neurology.org/about/about_the_journal\#permissions }\end{array}$ \\
\hline Reprints & $\begin{array}{l}\text { Information about ordering reprints can be found online: } \\
\mathrm{http} / / / \mathrm{n} \text {.neurology.org/subscribers/advertise }\end{array}$ \\
\hline
\end{tabular}

Neurology ${ }^{\circledR}$ is the official journal of the American Academy of Neurology. Published continuously since 1951, it is now a weekly with 48 issues per year. Copyright @ 2016 American Academy of Neurology. All rights reserved. Print ISSN: 0028-3878. Online ISSN: 1526-632X.

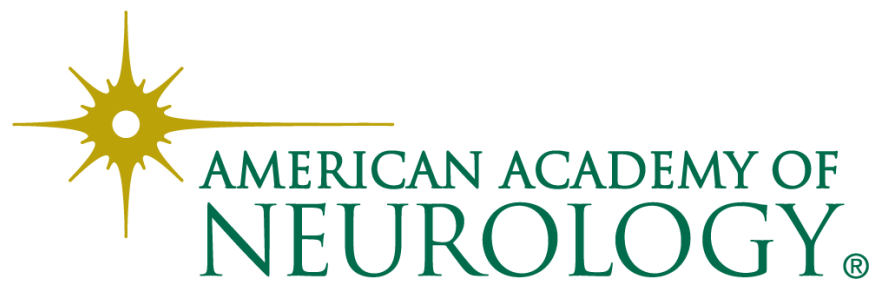

